\title{
"Evaluating the economic and ecological effects of investment projects: A new model and its application to smartphone manufacturing in Europe"
}

\begin{tabular}{|c|c|}
\hline AUTHORS & $\begin{array}{l}\text { Viktoriia Apalkova (i) } \\
\text { Sergiy Tsyganov (i) } \\
\text { Tetiana Chernytska (D) } \\
\text { Nataliia Meshko (i) } \\
\text { Nadiia Tsyganova (D) } \\
\text { R }\end{array}$ \\
\hline ARTICLE INFO & $\begin{array}{l}\text { Viktoriia Apalkova, Sergiy Tsyganov, Tetiana Chernytska, Nataliia Meshko and } \\
\text { Nadiia Tsyganova (2021). Evaluating the economic and ecological effects of } \\
\text { investment projects: A new model and its application to smartphone } \\
\text { manufacturing in Europe. Investment Management and Financial Innovations, } \\
\text { 18(4), 252-265. doi:10.21511/imfi.18(4).2021.22 }\end{array}$ \\
\hline DOI & http://dx.doi.org/10.21511/imfi.18(4).2021.22 \\
\hline RELEASED ON & Tuesday, 30 November 2021 \\
\hline RECEIVED ON & Friday, 22 October 2021 \\
\hline ACCEPTED ON & Tuesday, 23 November 2021 \\
\hline LICENSE & $\begin{array}{l}(c) E Y \quad E \\
\text { This work is licensed under a Creative Commons Attribution } 4.0 \text { International } \\
\text { License }\end{array}$ \\
\hline JOURNAL & "Investment Management and Financial Innovations" \\
\hline ISSN PRINT & $1810-4967$ \\
\hline ISSN ONLINE & $1812-9358$ \\
\hline PUBLISHER & LLC “Consulting Publishing Company "Business Perspectives" \\
\hline FOUNDER & LLC "Consulting Publishing Company "Business Perspectives" \\
\hline
\end{tabular}

NUMBER OF REFERENCES

30

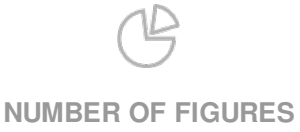

5

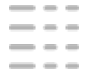

NUMBER OF TABLES

3

(C) The author(s) 2021. This publication is an open access article. 


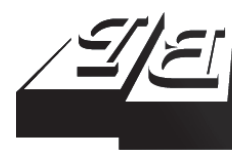

\section{BUSINESS PERSPECTIVES}

LLC "CPC "Business Perspectives" Hryhorii Skovoroda lane, 10, Sumy, 40022, Ukraine www.businessperspectives.org

Received on: $22^{\text {nd }}$ of October, 2021 Accepted on: $23^{\text {rd }}$ of November, 2021 Published on: $30^{\text {th }}$ of November, 2021

(c) Viktoriia Apalkova, Sergiy Tsyganov, Tetiana Chernytska, Nataliia Meshko, Nadiia Tsyganova, 2021

Viktoriia Apalkova, Ph.D. in Economics, Associate Professor, Faculty of International Economics and Management, Department of International Economics, Kyiv National Economic University named after Vadym Hetman, Ukraine. (Corresponding author)

Sergiy Tsyganov, Doctor of Economics, Professor, Institute of International Relations, Department of International Finance of the Institute of International Relations, Taras Shevchenko National University of Kyiv, Ukraine.

Tetiana Chernytska, Ph.D. in Economics, Associate Professor, Faculty of International Economics and Management, Department of International Economics, Kyiv National Economic University named after Vadym Hetman, Ukraine.

Nataliia Meshko, Doctor of Economics, Professor, Head of the Department of Marketing and International Management, Faculty of Economics, Department of Marketing and International Management, Oles Honchar Dnipro National University, Ukraine.

Nadiia Tsyganova, Doctor of Economics, Associate Professor, Banking and Insurance Department, Kyiv National Economic University named after Vadym Hetman, Ukraine.

This is an Open Access article, distributed under the terms of the Creative Commons Attribution 4.0 International license, which permits unrestricted re-use, distribution, and reproduction in any medium, provided the original work is properly cited.

Conflict of interest statement: Author(s) reported no conflict of interest
Viktoriia Apalkova (Ukraine), Sergiy Tsyganov (Ukraine), Tetiana Chernytska (Ukraine), Nataliia Meshko (Ukraine), Nadiia Tsyganova (Ukraine)

\section{EVALUATING THE ECONOMIC AND ECOLOGICAL EFFECTS OF INVESTMENT PROJECTS: A NEW MODEL AND ITS APPLICATION TO SMARTPHONE MANUFACTURING IN EUROPE}

\begin{abstract}
Despite market volatility in 2020 due to the COVID-19 pandemic and a decline in global investment flows to 2005 levels, sustainable development funds continued to grow. These data indicate a change in development vectors: now leading investors are guided by technologies for sustainable growth. The purpose of this paper is to determine the optimal model for evaluating investment projects in terms of their economic and environmental effects on the development of the region. The proposed technique is being tested for an investment project aimed at developing the production of mobile phones in Europe. As shown, the analysis of the location of the production of smartphones in Europe for subsequent implementation in the European market has a number of advantages and is more beneficial in terms of environmental and economic effects for the region. First, from an economic point of view, this leads to an increase in the volume of attracted investments, a decrease in operating costs for international logistics, the creation of new jobs and qualifications for the population. In addition, it is important to be able to actively implement circular business models that will reuse lithium-ion phone batteries, which will lead to a decrease in the need for cobalt as a raw material, as well as lead to an increase in the level of recycling of e-waste and the circularity of the European economy. Also, such investment projects open up great opportunities for manufacturers from a marketing point of view, creating bonuses for a positive image and preferences for a "local green producer".
\end{abstract}

Keywords

investment project, smartphone manufacturing, carbon footprint, marketing research, circular economy

JEL Classification F64, F21, O31

\section{INTRODUCTION}

The COVID-19 pandemic has caused global investment flows to plummet in 2020 to 2005 levels. In 2020, global investment fell by $35 \%$ - from $\$ 1.5$ trillion to less than $\$ 1$ trillion, much more than during the global economic crisis in 2008, when the decline was at the level of $20 \%$ (UNCTAD, 2021). It should be noted that developing countries and transitional economies have weeded the reduction in global investment flows much easier than developed countries.

The United Nations Conference on Trade and Development estimates global investments in sustainable development projects in 2020 at $\$ 3.2$ trillion, indicating an increase of more than 80 percent compared to 2019. These projects include: sustainable funds - more than $\$ 1.7$ trillion; environmental projects - more than $\$ 1$ trillion; social bonds $\$ 212$ billion, and mixed sustainability bonds - \$218 billion. 
The vast majority of them are located in developed countries and work with the assets of developed financial markets. Sustainable development funds continued to grow, despite market destabilization in 2020. Their number increased to almost 4,000 by the summer of 2020, which is $1 / 3$ more than in 2019 . It should also be emphasized that managed assets currently account for 3.3 per cent of total open fund assets in the world.

These data indicate a change in development vectors: now leading investors are guided by sustainable growth technologies, which can be partially or formally explained by the increase in the cost of the carbon footprint (for example, in Europe ETS, the cost of carbon increased from 5.31 in 2016 to 50.07 euros in 2021 year, that is, almost 10 times), and partly by an increase in awareness of the consequences of global climate change. Leaders of many international companies, as well as governments, are now increasingly raising the topic of ecology and the need for decoupling, the introduction of circular production models and minimizing the carbon footprint.

In this regard, the question arises of assessing not only economic but also environmental effects of investment projects.

Another aspect to consider is the growing role of technology companies in today's global economic system. According to the UNCTAD report, despite the COVID-19 crisis, asset sales in the digital industry (mainly in the production of computers, electronics, optics and household appliances, as well as in information and technology) increased significantly in 2020.

It should be noted that, despite geopolitical and geoeconomic destabilization and uncertainty in international commercial relations, multinational corporations define China as a strategic market for foreign direct investment. This confidence is facilitated by a favorable investment environment in China. Also attractive for global investors are urbanization and the growing well-being of the population, the development of advanced technologies, as well as highly developed infrastructure. At the same time, it is necessary to note a number of crisis phenomena in China. Firstly, problems with container deliveries from China around the world, which resulted in higher delivery costs and failures in supply chains. Defaults of state-owned companies of the PRC in 2020 caused some tension, and in 2021 - the country's largest developer Evergrande, whose debt is estimated at more than $\$ 300$ billion. Given that the Chinese economy is $30 \%$ composed of construction and related industries, the projected $8 \%$ growth of the economy becomes unattainable. It is also important to note the increase in the overall debt burden of the economy. Another serious risk came in September 2021 - the growing energy crisis in China, the consequences of which have already been the disconnection of a significant number of industrial factories from energy supplies in a number of provinces, and in others - the transition to a floating schedule (in order to save energy resources). This situation threatens the flow of foreign investment into the country. They also do not add to the investment attractiveness of the PRC's position on international political issues, in particular, the aggravation of relations with Taiwan, as well as political and economic confrontation with the United States. Given the experts' forecasts regarding the end of the period of synchronous monetary easing for developing countries, one can argue that the balance of the structure of global investment flows will be gradually redistributed from developing countries to developed ones. This point is confirmed by the fact that developed countries suffered twice as much from reducing FDI into projects from zero, which play a decisive role in sustainable development. Also an important goal for modern manufacturers is to reduce the logistics shoulder, which will positively affect the cost of final products.

In this regard, the question arises regarding the adequacy of the existing global economic production infrastructure to the modern challenges associated with pandemic and climate change, as well as the goals of the transition to the principles of a circular and low-carbon economy.

Today, an overwhelming majority of countries, international organizations and corporations include in their economic policy and development strategy issues related to improving the quality of products, creat- 
ing additional value for consumers, as well as greening their activities and protecting the environment. This has become particularly relevant in recent years, due to increased environmental awareness and awareness of consumers. Before making a decision, leading actors of the world arena recommend a comprehensive assessment of all projects, taking into account not only economic, but also environmental factors.

\section{LITERATURE REVIEW}

An investment project requires a number of conditions that can guarantee the successful implementation of capital investment. This is a guarantee that project implementation will bring specific benefits, most often profit, but recently the list of indices has expanded significantly, since now an increasingly important criterion in the development, selection and implementation of investment projects is their environmental efficiency. Thus, today the topic of identification and analysis of all non-economic consequences of the realization of investment projects is becoming relevant.

In modern UN documents on environment and development, the line of balanced sustainable development of society and economy in accordance with the interests of modern and future generations is often traced (Desa, 2016). This concept is seen as an alternative to unlimited economic growth on a global scale, which has led to the degradation of the biosphere. Therefore, a transition is needed to formulate the problem of environmental protection together with economic growth through investment.

It should be noted that quite a few researchers have dealt with issues related to the need to include environmental indicators in the palette of mandatory investment criteria (Markusson, 2010; Shvetsova \& Lee, 2020; Gao \& Zhang, 2013; Kulczycka \& Smol, 2016, and others).

Many of the works focus on one economic sector. For example, Markusson (2010) has based his article on case studies of investment projects in technological processes at chemical and dairy companies in the UK and Sweden. The author analyzes the prospects of the political process in organizations, as well as the behavior of environmentalists in investment projects.

Other articles study the environmental efficiency in the investment processes of specific countries.
For example, Shvetsova and Lee (2020) used South Korea as an example to address theoretical and practical questions regarding investment financing for industrial waste management in industrialized countries. The authors studied the problems of forming sustainable industrial waste disposal management systems and discussed the practical application of the environmental policy of South Korean companies. They used MCDM methods to analyze the performance of waste management investment projects in Korea, mainly focusing on risk.

It should be noted that traditional research examines the impact of foreign investment on technology diffusion or the environment separately. However, Gao and Zhang (2013) took a more comprehensive approach in their article and analyzed the relationship between foreign investment, innovation potential and environmental performance. Their results revealed that foreign investment can directly contribute to both local environmental efficiency and local innovation capacity.

A similar integrated approach is characteristic of the work of Kulczycka et al. (2016), where researchers proposed the widespread use of the life cycle assessment model for both environmental analysis (LCA - Life Cycle Assessment) and economic cost analysis (LCCA - Life Cycle Cost Assessment) in investment management. In their opinion, the combination of LCA and LCCA outcomes allows assessing the modern or planned investments and can be very beneficial in making strategic decisions.

\subsection{Environmental performance assessment in the information technology sector}

Since the choice of the information technology sector is assumed as an approbation of the proposed assessment model for economic and environmental performance of an investment project, it is necessary to study the existing developments and research in this particular industry. 
Digital technologies and electronics are rapidly becoming a key factor in the functioning of the modern world. Recent innovations in algorithms, software and hardware have begun to provide all kinds of mobile apps for a comfortable life in virtually every service from the financial sector to healthcare and home. However, as mobile devices become more common, their impact on the environment has also increased.

It is worth noting that many studies have explored certain aspects of the impact of the information technology industry on the environment: Gupta et al. (2021), Calero et al. (2019), Rawat et al. (2017), Kalange et al. (2018), and others.

Calero et al. (2019) investigated whether software companies align their corporate responsibility strategies with the UN Sustainable Development Goals. Their analysis showed that sustainability is considered in most companies. However, the current focus is on initiatives aimed at reducing the carbon footprint of companies' hardware resources.

Part of the research is devoted to the issues of energy consumption by information systems (Mattila et al., 2014; Chowdhury et al., 2013, and others).

For instance, Chowdhury et al. (2013) attempted to analyze the energy consumption of cloud computing by examining the clouds supported by specific organizations and observing the energy benefits they receive. The authors also conducted research that can help reduce the carbon footprint through green cloud computing.

In addition, Gupta et al. (2021) performed an analysis based on the characteristics presented in the industry reports, and quantified the impact of computers on the environment in terms of carbon emissions. According to their study, carbon emissions come from two sources such as operational energy consumption and the production of equipment and infrastructure. While carbon emissions from the first cause are declining thanks to innovations that improve productivity and energy efficiency, the overall carbon footprint of computer systems continues to grow. The authors conclude that most carbon emissions come from equipment and infrastructure manufacturing.
In this context, interesting research related to the use of circular business models to minimize the negative effects of the production of computer equipment, as well as consumer electronics.

One of the earliest studies on this topic is the work of Bakker and Kuijer (2014), where the authors provide a comprehensive analysis of the use of built-in batteries in mobile phones and computer technology. Despite certain positive functionality, such a technological solution provoked many problems associated with unauthorized repairs and the inconvenience of removing for reuse and starting a circular cycle, etc. Consequently, the authors conclude that this ultimately leads to serious environmental consequences and requires new technological solutions and improvements.

Later, many studies were conducted on the problem of lithium-ion batteries in smartphones and other technology (Velázquez-Martínez et al., 2019; Mossali et al., 2020). They are now widely used in advanced technology devices due to their high energy, light weight, reduced memory effect and significant number of supported charge cycles. As a result, their production is growing and their use will constantly increase, while the attention of the world community will be focused on their disposal. Mossali et al. (2020) analyzed the existing manufacturing processes and technical solutions provided by research projects and industrial development and conducted a detailed literature review comparing the best results with open issues. From this, the authors conclude that recycling of used lithium-ion batteries is still under development and the process cannot be optimized. At the same time, recycling is currently the only alternative to social, economic and environmental sustainability in this market that can minimize waste toxicity.

\subsection{Development of the circular economy concept}

Today, the concept of a circular economy (CE) is increasingly seen as the key to improving the efficiency of global production, logistics and distribution systems through the optimization of processes involved in waste management, new recycling and renovation technologies, and the creation of new business models. In addition, the circular economy allows society to solve the main problem 
such as the depletion of natural resources that are used as raw materials for the global economy.

It should be noted that this concept is based on a fairly large layer of research related to the study of the problems of reuse, recovery or recycling (Lieder \& Rashid, 2016; Cramer, 2020; Khan et al., 2020 , and others).

In their work, Lieder and Rashid (2016) performed a very detailed literary review of the existing research in the field of circular economics and divided them into three main groups by subject matter: 1) the problem of scarcity or limitation of resources; 2) waste generation problem; and 3) the means of obtaining economic benefits. They also pay special attention to studies focusing on integrated solutions for the above three problems (resources, environment, and economic potential). As a result, they provided an analysis of the motivation for the development of a circular economy for its various participants, and also concluded that the maximum effect on a global scale is possible only with the assistance of all parties.

An interesting is the study by Cramer (2020) where the author, based on a thorough analysis of the effectiveness of the implementation of circular projects and initiatives in Amsterdam (Netherlands), makes two interesting conclusions. First, it cannot be argued that circular initiatives in themselves lead to gradual changes in the economy. Secondly, in order for such initiatives to really shape transformation processes, they must consistently and continuously develop by complementing new and new larger-scale projects and initiatives. As in the previous study, the author also analyzed the motivational component of all participants, and concluded that the maximum effect is achieved where the interests of the authorities (regime) and the initiators coincide.

In the modern paradigm of global development, the circular economy must clearly be the basic strategy for achieving corporate sustainability.

At the same time, Beulque and Aggeri (2016), based on their thorough analysis of the implementation of international projects in this area, argue that companies would start developing circular business models faster and much earlier if the re- al cost of traditional resources would not undergo constant decline in the world market. They also, like previous authors, insist on the importance of understanding and support from world leaders of the relevance of circular businesses.

Thus, while life extension and other circular technologies hold promise in the transition to circular economy, business models and policies in specific industries are poorly understood in the literature, and existing research is fragmented and sometimes contradictory.

The purpose of this paper is to determine the optimal model for evaluating investment projects in specific industries in terms of their economic and environmental effects on the development of the region.

\section{METHOD}

As a rule, the assessment of the investment strategy of an enterprise refers to internal management processes, and therefore mainly includes project performance indicators, including internal rate of return, net present value, payback period, profitability index, ets.

However, this study proposes a method for evaluating an investment strategy for an industry in terms of economic and environmental effects that its implementation will have. Moreover, these effects relate not so much to an enterprise itself (although they also matter), but to the entire environment.

Therefore, any investment project must include the following main phases:

I. Marketing research, including capacity and development dynamics assessment, competitor analysis, analysis of the raw material base, consumer analysis, SWOT and PESTLE analysis and other components.

II. Creation of a product concept with the assignment of a unique value proposition (UVP).

3. Preparation of the financial model of a project, with forecast reports on profit, cash flow, 
balance sheet, as well as calculations of the economic efficiency of the project (net present value (NPV), internal rate of return (IRR), payback period (PP), discounted payback pe$\operatorname{riod}(\mathrm{DPP})$, etc.).

It is proposed to expand this list to include a fourth phase, namely:

\section{Assessment of the economic and environmen-} tal impact of the development of a project for the region, which includes the calculation of the carbon footprint from the project implementation, carbon intensity per invested capital, carbon intensity per generated revenue and others.

In addition, it is important to include an analysis of the carbon footprint of the industry at the stage of marketing research.

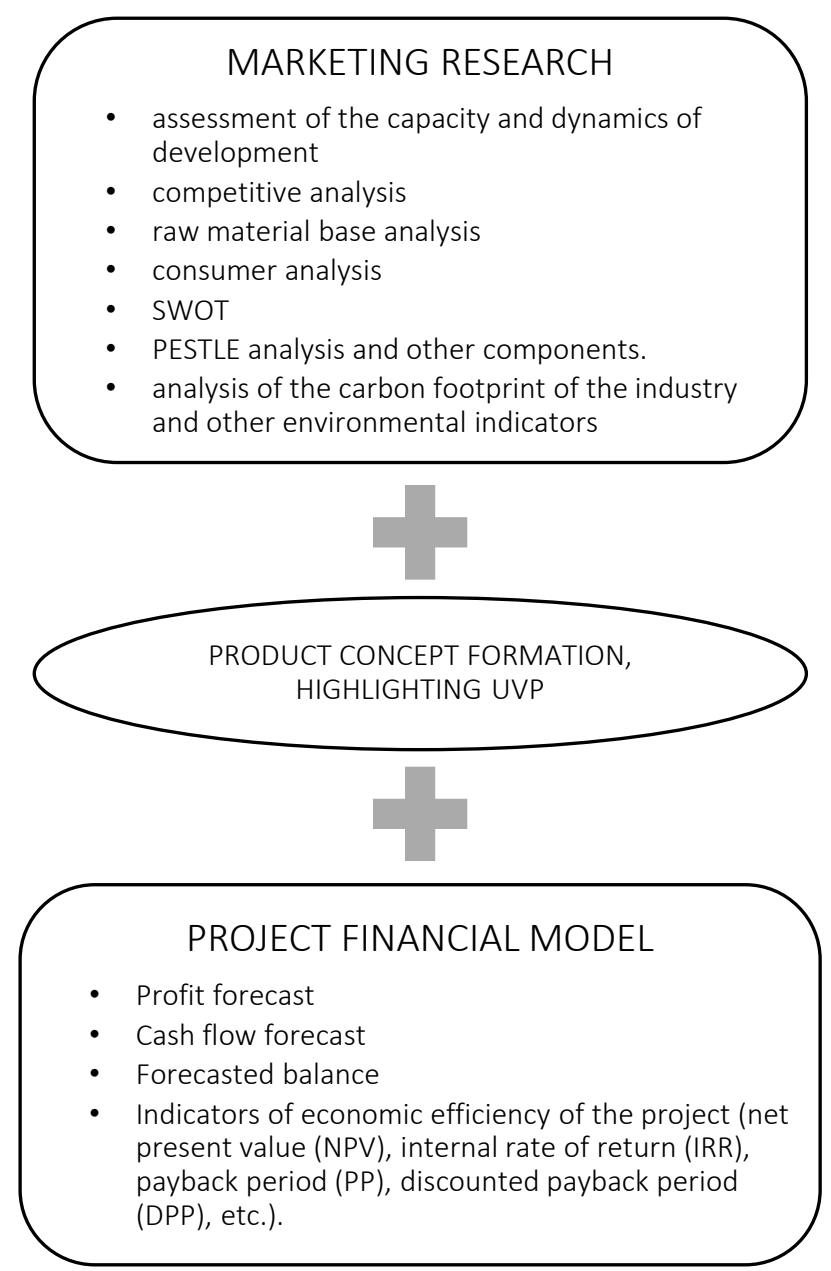

It should be noted that it is already becoming relevant to analyze the dynamics of the cost of the EU ETS or carbon tax, as this can significantly affect the profitability of the implementation and, ultimately, the return on investment.

Thus, the scheme for preparing an investment proposal will be expanded to include indicators of environmental performance. They are highlighted in red in Figure 1.

As follows from the algorithm proposed above, the assessment of the economic and environmental effect from the development of the project for the region is the resulting stage, the indicators of which are closely intertwined and follow from the indices of the previous stages. Therefore, in order to correctly analyze and obtain the optimal result, a special analytical tool "Matrix of Economic and Carbon Impact
EVALUATION OF THE PROJECT ON ITS ECONOMIC AND ENVIRONMENTAL IMPACT IN THE REGION

\section{Environmental}

- calculating the carbon footprint of the project, carbon intensity per invested capital, carbon intensity per generated revenue and others

Economic

- the level of attracted investments, new jobs, etc.

Figure 1. Key stages in preparing of an investment model using environmental indicators 
Table 1. Matrix of economic and green impact effects

Source: Developed by the authors.

\begin{tabular}{|c|c|c|c|}
\hline \multicolumn{2}{|r|}{$\begin{array}{l}\text { Input - Investment project of consumer electronics } \\
\text { manufacturing }\end{array}$} & \multicolumn{2}{|r|}{ External effects } \\
\hline $\mathbf{I}$ & Economic indices of an Investment Project & III & Economic indices \\
\hline 1. & Investment expenditures & 1. & $\begin{array}{l}\text { Inflow/Outflow of Investments in Industry (FDI + Local } \\
\text { Investments) }\end{array}$ \\
\hline 2. & Sales & 2. & Local products / Import of finished products \\
\hline 3. & Costs & 3. & Local / Imported / Recycled raw materials and supplies \\
\hline 3.1. & Raw materials and supplies & 4. & Number of new jobs, number of qualified personnel \\
\hline 3.2. & People & 5. & Local distribution / Local and international distribution \\
\hline 3.3. & Logistics & 6. & $\begin{array}{l}\text { Image of local producer / Image of growing import } \\
\text { dependence }\end{array}$ \\
\hline 3.4 & Marketing & 7. & Local budget inflows \\
\hline 3.5. & Taxes & 8. & Local R\&D expenses \\
\hline 3.6. & $R \& D$ & & \\
\hline II & Green indices of an Investment Project & IV & Green indices \\
\hline 1. & Carbon Intensity per USD 1 Million Invested & 1. & Total carbon emissions \\
\hline 2. & Carbon Intensity per USD 1 Million of Revenue Generated & 2. & Recycling rate of e-waste \\
\hline 3. & $\begin{array}{l}\text { Weighted average carbon intensity (emissions per USD } 1 \\
\text { million of revenue generated) }\end{array}$ & 3. & Circular material use rate (\%) \\
\hline 4. & Fossil Fuel Reserve Emissions per USD 1 Million Invested & & \\
\hline
\end{tabular}

Effects" (see Table 1) is offered, which involves four quadrants of analysis.

The first and second quadrants relate to the analysis of the indicators of the investment project itself. The third and fourth are devoted to indicators of externalities from the implementation of the project, that is, what impact it will have on the economy and environment of the region. At the same time, the economic indicators of the third quadrant are a consequence of the indicators of the first quadrant. While the environmental indicators of the fourth quadrant are based on the indicators of the second quadrant, taking into account the indicators of the third. Thus, from the point of view of environmental and, to some extent, economic efficiency (since the carbon footprint already has a clear value in developed markets) the fourth quadrant is the resultant.

When it comes to calculating the carbon footprint for an industry, there are many approaches.

This study proposes to use a generalized approach, which stipulates that the total carbon footprint of an industry equals the sum of the carbon footprints of all products in a given industry over a one-year period of time:

$$
F C O(2)_{\text {Industry }}=Q_{\text {Industry }} \cdot F C O(2)_{\text {Product }} \text {, }
$$

where $F C O(2)_{\text {Industry }}$ - industry carbon footprint on an annualized basis, $Q_{\text {Industry }}$ - industry market capacity in quantitative terms, and $F C O(2)_{\text {Product }}$ - annual carbon footprint of a specific single product.

In addition, to calculate the environmental indicators of investment projects, in particular, such as carbon intensity per invested capital, carbon intensity per generated revenue and others, it is proposed to use the S\&P Global methodology - Index Carbon Metrics Explained.

\section{RESULTS}

To test the above presented method for assessing the investment strategy in terms of economic and environmental effects, it is proposed to take the European mobile phone market, which is currently represented mainly by imports. Following the logic of the model, at the first stage it is necessary to conduct a marketing research of the market. Obviously, for the implementation of a specific investment project, a deep analysis of the market situation and other indicators is required, which is not the purpose of this paper, since the methods themselves are more important to us, rather than trends. At the same time, it seems appropriate to give a brief overview of the market from the point 
of view of its business model and the specifics of development in Europe in terms of indicators that especially affect the carbon footprint of this industry and the efficiency of its use.

\subsection{Results of a brief marketing research of the smartphone market in Europe}

The mobile phone market in the EU is experiencing a saturation period. The analysis of statistical data (Appendix A) shows that imports are the main source of supply of this product to consumers in Europe. Local production has insignificant volumes and is practically not represented. There is export, but this is mainly a redistribution of import flows within regional networks. Also, starting from 2013, there is a clear downward trend in the import of mobile phones.

This situation is not surprising, since the consumer market has been saturated. If in 2008 the level of sales of mobile phones per capita was 0.57 , then in 2013 it dropped to 0.4 , and by 2020 it was 0.33 .

At the same time, if we calculate how much during this time (from 2008 to 2020) was imported and left (not exported) in Europe, then this figure will be 2.358 billion mobile phones. In the context of countries and in terms of weight, these figures are even more significant. So, for example, in France for the period from 2008 to 2020.470 million phones were imported with a total weight of 140 thousand tons.

At the same time, the share of the European Union (27) in the global imports of mobile phones is $16 \%$ (Appendix A). China is the main exporter of mobile phones (52\% in 2020). Every year it exports more than 1 billion phones around the world, in 2020 alone, the total weight of exports under the code 851712 amounted to 266.7 thousand tons.

Since $16 \%$ of this volume is supplied to Europe, and the average consumption cycle before replacing a telephone is less than three years, it turns out that about more than 60 thousand tons are accumulated annually in the EU alone (27).

For the analysis of the carbon footprint for the smartphone industry in Europe, formula (1) can be used. According to many analytical publications, the annual hydrogen footprint from one mobile phone is about $71 \mathrm{~kg} /$ year (Matt Thorne, Honest Mobile). Thus, multiplying this indicator by the annual capacity in quantitative terms, the estimated level of the carbon footprint of the smartphone industry in Europe is obtained (Figure 4).

As can be seen, in general, there is a positive trend in reducing the carbon footprint of the smartphone industry in Europe. However, the obvious

\section{Dynamics of the capacity of the mobile phone market in the EU (27)}

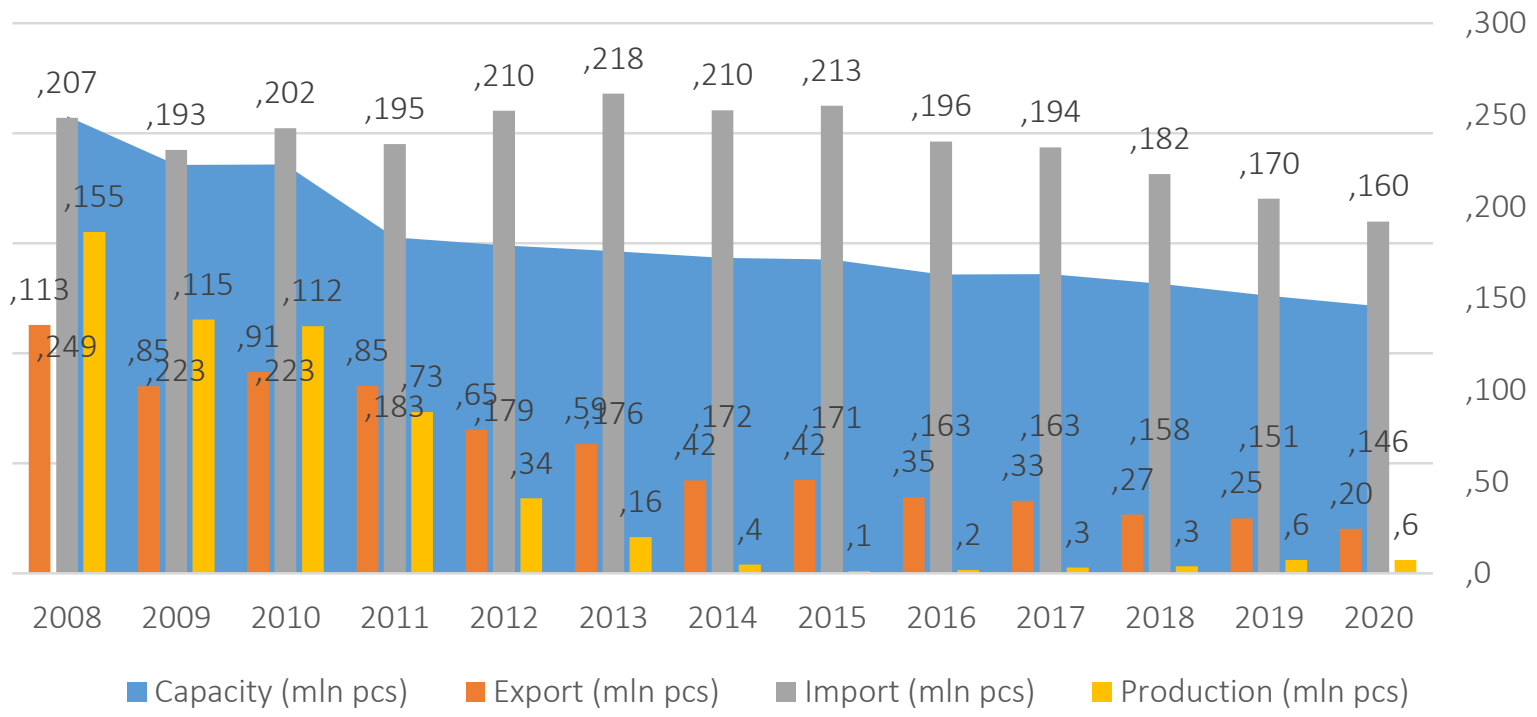

Figure 2. The structure and dynamics of the capacity of the mobile phone market in the EU (27) 


\section{Sales of mobile phones per capita}

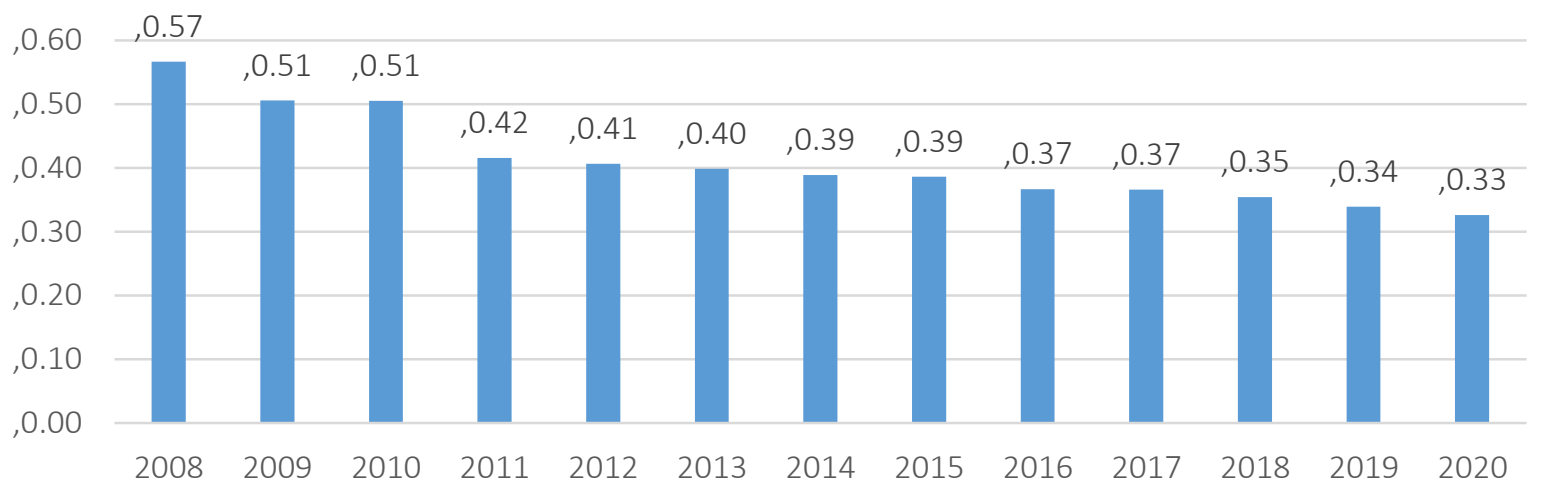

Figure 3. Sales of mobile phones per capita in the EU (27)

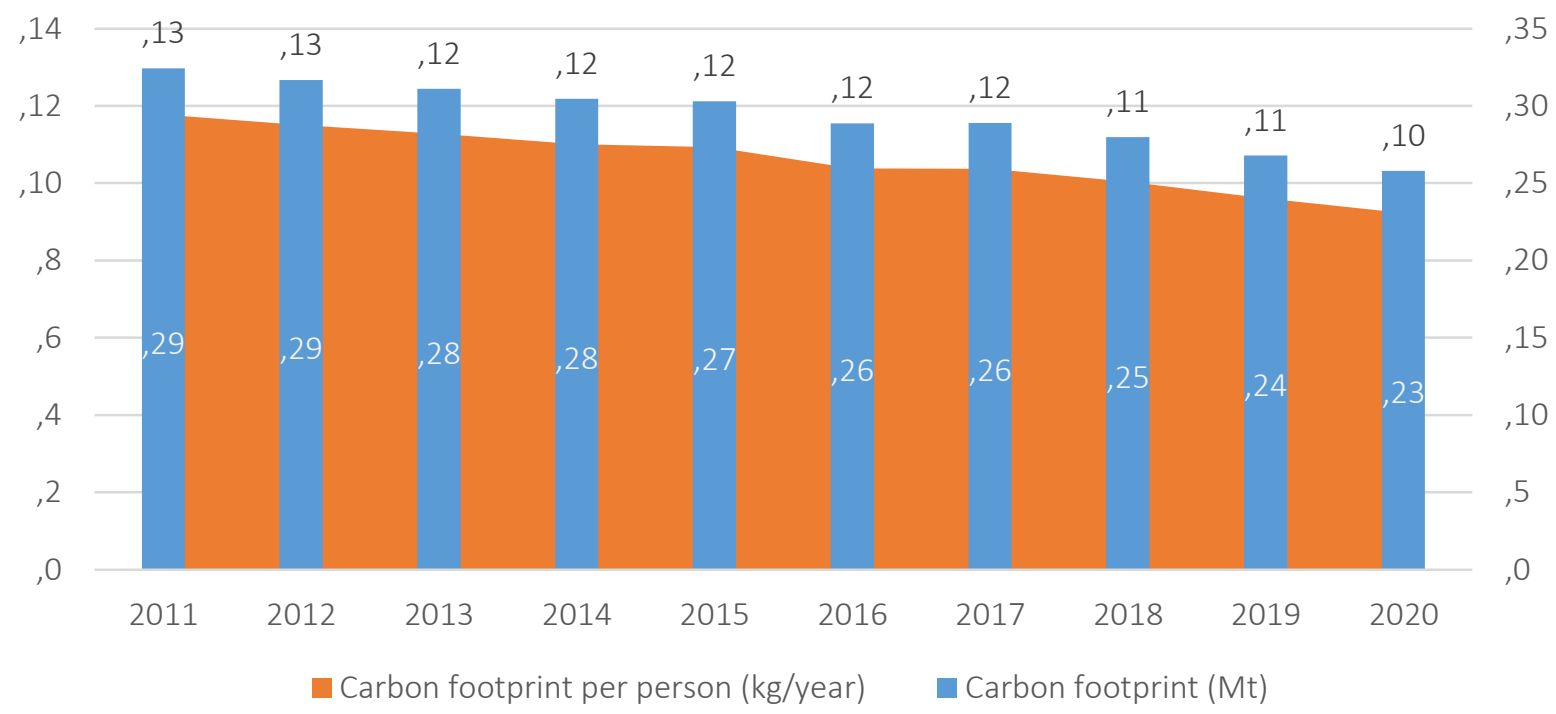

Figure 4. Carbon footprint of the smartphone market in the EU (27)

reason is a decrease in market capacity, which, in turn, is caused, as noted above, by a decrease in imports. The second aspect is related to the efficiency of using the carbon footprint, because it is formed through imports and does not in any way affect many of the region's economic indicators, such as job creation in production, attracting investment to the region, etc. It also creates a buildup of e-waste that could be used to re-manufacture phones if an advisory manufacturing base were located in Europe.

In this regard, the question arises about the relevance of organizing the production of smartphones in Europe with the introduction of technologies for the renovation of old models. Thus, it is necessary to move on to the next stage of the model.

\subsection{Creating a product concept with the assignment of a unique value proposition (UVP)}

It should be noted that there can be many variations of DRM, depending on the brand, target audience, technological capabilities, etc. But in the context of this study, it is necessary to pay attention to the following key characteristics of the product, which can be used to identify its unique value proposition, namely, the application of the circular model to the manufacture of the phone.

Since production is local, it can provide the functionality of reworking old models or renovating them. It should be noted that the circular business models associated with the development of the mobile phone industry include recycling in three 


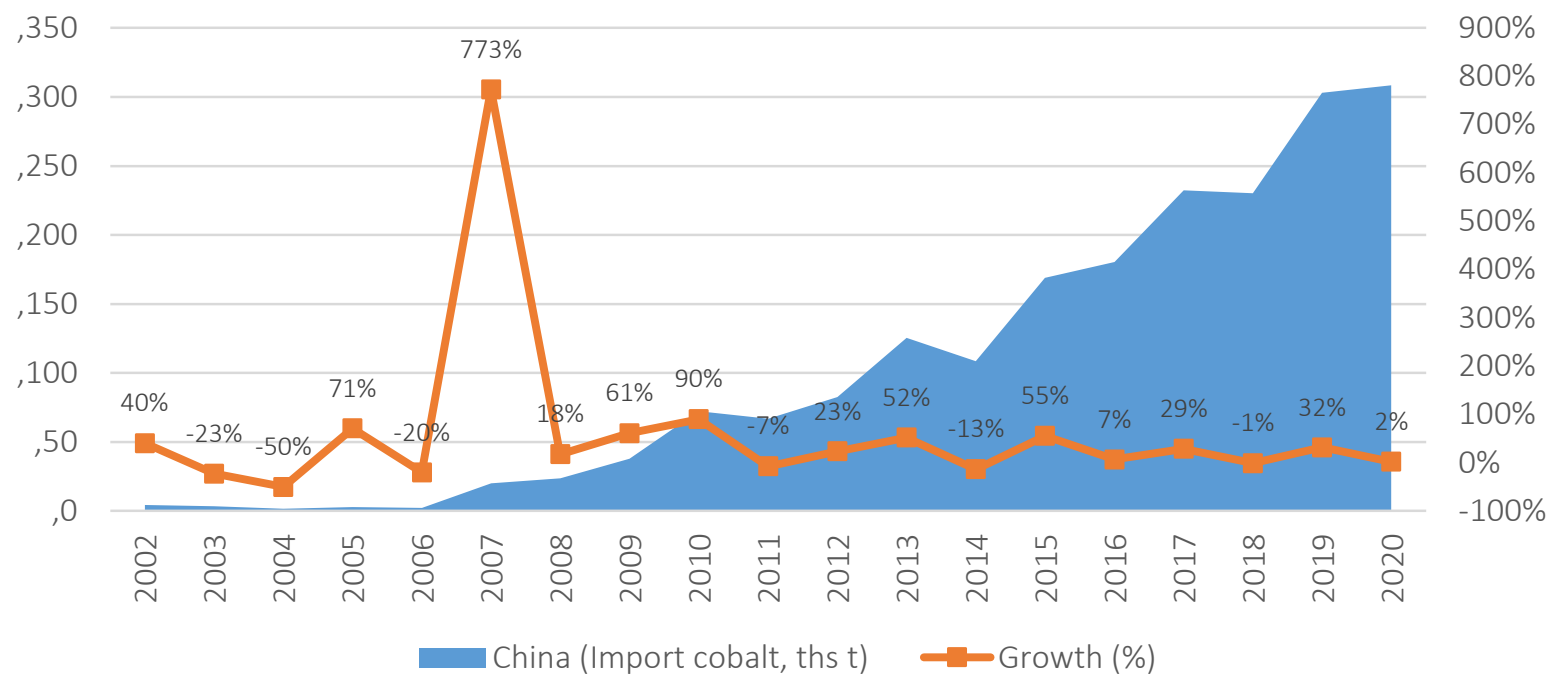

Figure 5. Cobalt imports by China for the period 2002-2020 (ths t)

main areas: 1) LCD screens, 2) Lithium-ion batteries, and 3) Printed circuit boards (PCBs). At the same time, at present, it is the recycling of lithium-ion batteries that is an urgent topic for research and development. In this context, the question arises about the prospects of collecting old mobile phones and producing new ones on their basis in Europe itself, avoiding the economic and environmental costs of logistics, as well as getting the opportunity to develop their own technologies.

Next comes the stage associated with the preparation of the financial model of the project. As noted above, this involves the formation of forecast financial statements, in particular, on profit, cash flow, etc. In the context of this study, special attention should be paid to the raw material base for the production of smartphones. As noted, lithium-ion batteries are one of the main components of smartphones. At the moment, lithium-ion batteries are fraught with two main problems: Firstly, for their production, cobalt is needed, which is a limited natural resource; in addition, not only manufacturers of phones, but also laptops and electric cars claim it. The main reserves of cobalt are concentrated in the Congo, and the key importer is China, while annually imports are growing dynamically and by 2020 reached 309 thousand tons (Figure 5).

Secondly, there are problems with the recycling of lithium-ion batteries, since today, according to practitioners, existing installations for the re- cycling of lithium-ion batteries are expensive in construction and require sophisticated equipment to handle the harmful emissions generated during the smelting process.

It should be noted that the recycling of lithium-ion batteries is currently a hot topic for research and development. Scientists around the world are working to tackle this problem, while companies like Tesla are working on circular recycling programs to completely recycle and reuse all the batteries they put into their cars (insert link). The European Patent Office has over 11,444 patent applications related to Lithium-ion Batteries recycling, with over 560 already filed in 2021. Thus, it is only a matter of time when the technology will be presented that will allow restarting the production of mobile phones. This situation is an important argument for the fact that the production of mobile phones should be located in the EU and recycled lithium-ion batteries for the production of new models.

The last fourth stage includes an assessment of the economic and environmental impact of the development of a project for the region. It should be noted that the calculation of indicators in quantitative terms will depend on the specific configuration of the initiated investment projects, so at the moment it is not possible to test it by calculating all the components of the investment project. At the same time, one can assess the potential economic and green effects using a logical-deductive approach. 
Table 2. Comparative matrix of economic and green impact effects

Source: Developed by the authors.

\begin{tabular}{|c|c|c|c|}
\hline \multirow{2}{*}{\multicolumn{2}{|c|}{ External effects }} & \multicolumn{2}{|c|}{ Smartphone manufacturing } \\
\hline & & $\begin{array}{c}\text { Strategy } 1 \text { - Local production } \\
\text { (Europe) }\end{array}$ & $\begin{array}{c}\text { Strategy } 2 \text { - Production in China } \\
\text { (or other foreign region) }\end{array}$ \\
\hline \multicolumn{4}{|c|}{ III Economic indices } \\
\hline 1. & $\begin{array}{l}\text { Inflow/Outflow of Investments in } \\
\text { Industry (FDI + Local Investments) }\end{array}$ & $\begin{array}{c}\text { Inflow of Investments in Industry (FDI + } \\
\text { Local Investments) }\end{array}$ & Outflow of Investments (FDI) \\
\hline 2. & $\begin{array}{l}\text { Local products / Import of finished } \\
\text { products }\end{array}$ & Local products & Import of finished products \\
\hline 3. & $\begin{array}{l}\text { Local / Imported / Recycled raw } \\
\text { materials and supplies }\end{array}$ & $\begin{array}{l}\text { Import }+ \text { Collection and recycling of } \\
\text { electronic waste }\end{array}$ & $\begin{array}{c}\text { Import (import of cobalt from Congo for } \\
\text { battery production) }\end{array}$ \\
\hline 4. & $\begin{array}{l}\text { Number of new jobs, number of } \\
\text { qualified personnel }\end{array}$ & $\begin{array}{l}\text { New jobs for Europe, the need to train } \\
\text { personnel, growth of qualified personnel }\end{array}$ & Availability of qualified personnel \\
\hline 5. & $\begin{array}{l}\text { Local distribution / Local and } \\
\text { international distribution }\end{array}$ & Low logistic costs (only local distribution) & $\begin{array}{l}\text { High logistic costs (local + } \\
\text { international+local in China) }\end{array}$ \\
\hline 6. & $\begin{array}{l}\text { Image of local producer / Image of } \\
\text { growing import dependence }\end{array}$ & $\begin{array}{l}\text { Local and green image, high level of loyalty, } \\
\text { opportunities for implementation of leasing } \\
\text { business model }\end{array}$ & $\begin{array}{l}\text { High marketing costs because of low loyalty } \\
\text { to the brands }\end{array}$ \\
\hline 7. & Local budget inflows & More inflows for local budgets & Higher taxes because of import duties \\
\hline 8. & Local R\&D expenses & Higher local R\&D expenses & Indirect imported $R \& D$ expenses \\
\hline \multicolumn{4}{|c|}{ IV Green indices } \\
\hline 1. & Total carbon emissions & $\begin{array}{l}\text { Lower carbon emissions because } \\
\text { international trade excluded }\end{array}$ & $\begin{array}{l}\text { Carbon emissions higher because } \\
\text { international trade included }\end{array}$ \\
\hline 2. & Recycling rate of e-waste & $\begin{array}{l}\text { Higher (because local production is } \\
\text { available) }\end{array}$ & Lower \\
\hline 3. & Circular material use rate (\%) & $\begin{array}{c}\text { Higher (because local production is } \\
\text { available) }\end{array}$ & Lower \\
\hline
\end{tabular}

Thus, it is proposed to consider two alternative investment projects in terms of their economic and environmental effects. The first is related to the implementation of the strategy for developing local production and sale of smartphones in Europe. The second is following the traditional model - locating production in China or other Asian countries and selling finished products in Europe. The analysis will be carried out according to the proposed system Matrix of Economic and Green Impact Effects.

A detailed comparative analysis was performed in the Comparative Matrix of Economic and Green Impact Effects (Table 2).

As Table 2 shows, the analysis of the location of the production of mobile phones in Europe for subsequent implementation in the European market has many advantages and is more beneficial in terms of environmental and economic effects for the region.
First, from an economic point of view, this leads to an increase in the volume of attracted investments, a decrease in operating costs for international logistics, the creation of new jobs and qualifications for the population. In addition, it is important to be able to actively implement circular business models that will reuse lithium-ion phone batteries, which will lead to a reduction in the need for cobalt as a raw material, as well as lead to an increase in the level of recycling of e-waste and the circularity of the European economy.

In addition, such investment projects open up great opportunities for manufacturers from a marketing point of view, as they provide access to further customer loyalty when implementing the leasing business model, not to mention the positive image and preferences for "local green producers". The carbon footprint is already becoming a mainstream practice in product design and marketing.

\section{CONCLUSION}

Based on the study, the following conclusions can be drawn. The dynamic growth of investment funds, even in the face of a global decline in investment flows due to the crisis caused by COVID-19, speaks of 
a change in priorities in the minds of key investors. Another aspect to watch out for is the growing role of technology companies in today's global economic system.

The proposed method for assessing the investment strategy for industry in terms of economic and environmental effects provides for four stages: 1) market research, taking into account the analysis of the carbon footprint of the industry; 2) formation of a product concept, highlighting a unique value proposition with an emphasis on circularity; 3) preparation of a financial model of the project with the inclusion of a report on finding the optimal logistics and raw materials component in terms of carbon footprint; 4) an assessment of the economic and environmental impact of the development of the project for the region, which includes the calculation of the carbon footprint from the implementation of the project, carbon intensity per invested capital, and carbon intensity per generated revenue and others.

Testing this method for an investment project aimed at developing the production of mobile phones in Europe revealed a number of its advantages over the traditional location of production facilities in China and other Asian countries.

First, from an economic point of view, this leads to an increase in the volume of attracted investments, a decrease in operating costs for international logistics, and the creation of new jobs and qualifications for the population.

In addition, it is important to be able to actively implement circular business models that will reuse lithium-ion phone batteries, which will lead to a reduction in the need for cobalt as a raw material, as well as lead to an increase in the level of recycling of e-waste and the circularity of the European economy.

From a marketing perspective, these investment projects open great opportunities for manufacturers and create rewards for a positive image and preferences for a "local green producer".

In summary, it is clear that international telecommunication companies are raising questions about their responsibility for environmental and social impacts. On the other hand, circular business models involving the production-consumption-overproduction cycle are attracting more and more attention of MNEs in terms of new corporate and marketing opportunities.

\section{AUTHOR CONTRIBUTIONS}

Conceptualization: Viktoriia Apalkova, Sergiy Tsyganov, Nadiia Tsyganova.

Data curation: Viktoriia Apalkova, Nataliia Meshko.

Formal analysis: Viktoriia Apalkova, Sergiy Tsyganov, Nataliia Meshko, Nadiia Tsyganova.

Funding acquisition: Viktoriia Apalkova, Sergiy Tsyganov, Tetiana Chernytska, Nataliia Meshko, Nadiia

Tsyganova.

Investigation: Viktoriia Apalkova, Nataliia Meshko.

Methodology: Viktoriia Apalkova, Sergiy Tsyganov, Nadiia Tsyganova.

Project administration: Viktoriia Apalkova, Sergiy Tsyganov.

Resources: Viktoriia Apalkova, Tetiana Chernytska.

Software: Viktoriia Apalkova, Tetiana Chernytska.

Supervision: Viktoriia Apalkova, Sergiy Tsyganov, Nadiia Tsyganova.

Validation: Viktoriia Apalkova, Nataliia Meshko.

Visualization: Viktoriia Apalkova, Tetiana Chernytska.

Writing - original draft: Viktoriia Apalkova, Tetiana Chernytska.

Writing - review \& editing: Sergiy Tsyganov. 


\section{REFERENCES}

1. Bakker, C. A., \& Kuijer, L. (2014). More disposable than ever? Consequences of non-removable batteries in mobile devices. In Proceedings of CARE Innovation 2014 "Going Green" Conference. Vienna, Austria, 17-20 November 2014. Austrian Society for Systems Engineering and Automation.

2. Beulque, R., \& Aggeri, F. (2016, July). Circular Business Model Innovation: Key Patterns and Challenges to unleash recycling value creation potential. In EGOS

3. Calero, C., García-Rodríguez De Guzmán, I., Moraga, M. A., \& García, F. (2019) Is software sustainability considered in the CSR of software industry? International Journal of Sustainable Development \& World Ecology, 26(5), 439-459. https://doi.org/10.1080/13504509.2 019.1590746

4. Chowdhury, C. R., Chatterjee, A., Sardar, A., Agarwal, S., \& Nath, A. (2013). A comprehensive study on cloud green computing: To reduce carbon footprints using clouds. International Journal of Advanced Computer Research, 3(8), 78-85.

5. Cramer, J. M. (2020). Implementing the circular economy in the Amsterdam Metropolitan Area: The interplay between market actors mediated by transition brokers. Business Strategy and the Environment, 29(6), 2857-2870.

6. Desa, U. N. (2016). Transforming our world: The 2030 agenda for sustainable development.

7. European Commiission. (n.d.). EU Emissions Trading System. European Commission. Retrieved from https:// ec.europa.eu/clima/eu-action/euemissions-trading-system-eu-ets_en

8. Eurostat. (n.d.). European Statistical Dashboard. Retrieved from https:// ec.europa.eu/eurostat/web/main/ data/database

9. Gao, X., \& Zhang, W. (2013). Foreign investment, innovation capacity and environmental efficiency in China. Mathematical and Computer Modelling, 58(5-6), 1040-1046. https://doi.org/10.1016/j. mcm.2012.08.012
10. Gupta, U., Kim, Y. G., Lee, S., Tse, J., Lee, H. H. S., Wei, G. Y., Brooks, D., \& Wu, C. J. (2021, February). Chasing Carbon: The Elusive Environmental Footprint of Computing. In 2021 IEEE International Symposium on HighPerformance Computer Architecture (HPCA) (pp. 854-867). IEEE.

11. Han, J., Heshmati, A., \& Rashidghalam, M. (2020). Circular economy business models with a focus on servitization. Sustainability, 12(21), 8799. https://doi.org/10.3390/ su12218799

12. Honest Mobile. (n.d.). What's the carbon footprint of my smartphone? Aug 25, 2020. Retrieved from https:// honestmobile.co.uk/2020/08/25/ whats-the-carbon-footprint-of-mysmartphone/

13. Jones, N. (2018). How to stop data centres from gobbling up the world's electricity. Nature, 561(7722), 163-167.

14. Kalange, P. R., \& Jain, R. (2018). A Survey on Energy Efficiency \& Environmental Sustainability in Green Cloud Computing.

15. Khan, O., Daddi, T., \& Iraldo, F. (2020). Microfoundations of dynamic capabilities: Insights from circular economy business cases. Business Strategy and the Environment, 29(3), 1479-1493. https://doi.org/10.1002/bse.2447

16. Knieke, C., Lawrenz, S., Fröhling, M., Goldmann, D., \& Rausch, A. (2019). Predictive and flexible Circular Economy approaches for highly integrated products and their materials as given in E-Mobility and ICT. Materials Science Forum, 959, 22-31.

17. Kulczycka, J., \& Smol, M. (2016). Environmentally friendly pathways for the evaluation of investment projects using life cycle assessment (LCA) and life cycle cost analysis (LCCA). Clean Technologies and Environmental Policy, 18(3), 829842.

18. Lieder, M., \& Rashid, A. (2016). Towards circular economy implementation: a comprehensive review in context of manufacturing industry. Journal of Cleaner

Production, 115, 36-51. https://doi. org/10.1016/j.jclepro.2015.12.042

19. Markusson, N. (2010). The championing of environmental improvements in technology investment projects. Journal of Cleaner Production, 18(8), 777-783.

20. Matt Thorne. (2021). The carbon footprint of your phone - and how you can reduce it Feb 26, 2021. Retrieved from https://reboxed.co/ blogs/outsidethebox/the-carbonfootprint-of-your-phone-and-howyou-can-reduce-it.

21. Mattila, T., Judl, J., \& Seppälä, J. (2014). Carbon footprint of mobile devices: open questions in carbon footprinting of emerging mobile ICT technologies. Assessment of Carbon Footprint in Different Industrial Sectors, 1.

22. Mossali, E., Picone, N., Gentilini, L., Rodrìguez, O., Pérez, J. M., \& Colledani, M. (2020). Lithiumion batteries towards circular economy: A literature review of opportunities and issues of recycling treatments. Journal of Environmental Management, 264, 110500. http://dx.doi.org/10.1016/j. jenvman.2020.110500

23. Rawat, S., Kumar, P., Sagar, S., Singh, I., \& Garg, K. (2017, December). An analytical evaluation of challenges in Green cloud computing. In 2017 International Conference on Infocom Technologies and Unmanned Systems (Trends and Future Directions) (ICTUS) (pp. 351-355). IEEE.

24. S\&P Global. (n.d.). Index Carbon Metrics Explained. Retrieved from https://www.spglobal.com/spdji/ en/documents/additional-material/ spdji-esg-carbon-metrics.pdf

25. Sandberg, E., \& Hultberg, E. (2021). Dynamic capabilities for the scaling of circular business model initiatives in the fashion industry. Journal of Cleaner Production, 320, 128831. https://doi.org/10.1016/j. jclepro.2021.128831

26. Shvetsova, O. A., \& Lee, J. H. (2020). Minimizing the environmental 
impact of industrial production: Evidence from south Korean waste treatment investment projects. Applied Sciences, 10(10), 3489.

27. UN Comtrade Database. (n.d.). Repository of official international trade statistics and relevant analytical tables. Retrieved from https://comtrade.un.org/
28. UNCTAD. (2021). World Investment Report 2021. Investing in sustainable recovery. Retrieved from https://unctad.org/webflyer/worldinvestment-report-2021

29. Velázquez-Martínez, O., Valio, J., Santasalo-Aarnio, A., Reuter, M., \& Serna-Guerrero, R. (2019). A critical review of lithium-ion battery recycling processes from a circular economy perspective. Batteries, 5(4), 68. https://doi.org/10.3390/batteries5040068

30. Whalen, K. A., Milios, L., \& Nussholz, J. (2018). Bridging the gap: Barriers and potential for scaling reuse practices in the Swedish ICT sector. Resources, Conservation and Recycling, 135, 123-131.

\section{APPENDIX A}

Table A1. Key indices of the development of the mobile phone market in the EU

Source: Calculated by the authors based on the Eurostat and UN Comtrade Database data.

\begin{tabular}{|c|c|c|c|c|c|c|c|}
\hline $\begin{array}{c}\text { European } \\
\text { Union - } 27 \\
\text { countries } \\
\text { (from 2020) } \\
\end{array}$ & $\begin{array}{c}\text { EU Sales } \\
\text { of mobile } \\
\text { phones per } \\
\text { capita }\end{array}$ & $\begin{array}{c}\text { EU Recycling } \\
\text { rate of } \\
\text { e-waste }\end{array}$ & $\begin{array}{l}\text { EU Share } \\
\text { in global } \\
\text { import (\%) }\end{array}$ & $\begin{array}{l}\text { EU Capacity } \\
\text { (mln pcs) }\end{array}$ & $\begin{array}{l}\text { EU Export } \\
(\mathrm{mln} \text { pcs)* }\end{array}$ & $\begin{array}{l}\text { EU Import } \\
\text { (mln pcs)* }\end{array}$ & $\begin{array}{c}\text { EU } \\
\text { Production } \\
\text { (mln pcs) }\end{array}$ \\
\hline 2008 & 0,57 & & $16,72 \%$ & 249 & 113 & 207 & 155 \\
\hline 2009 & 0,51 & & $16,19 \%$ & 223 & 85 & 193 & 115 \\
\hline 2010 & 0,51 & 27,9 & $14,03 \%$ & 223 & 91 & 202 & 112 \\
\hline 2011 & 0,42 & 29,5 & $13,29 \%$ & 183 & 85 & 195 & 73 \\
\hline 2012 & 0,41 & 30 & $14,58 \%$ & 179 & 65 & 210 & 34 \\
\hline 2013 & 0,40 & 30,9 & $14,93 \%$ & 176 & 59 & 218 & 16 \\
\hline 2014 & 0,39 & 32,8 & $13,32 \%$ & 172 & 42 & 210 & 4 \\
\hline 2015 & 0,39 & 35,7 & $16,38 \%$ & 171 & 42 & 213 & 1 \\
\hline 2016 & 0,37 & 39,5 & $16,05 \%$ & 163 & 35 & 196 & 2 \\
\hline 2017 & 0,37 & 39,5 & $15,27 \%$ & 163 & 33 & 194 & 3 \\
\hline 2018 & 0,35 & 38,9 & $15,95 \%$ & 158 & 27 & 182 & 3 \\
\hline 2019 & 0,34 & & $14,42 \%$ & 151 & 25 & 170 & 6 \\
\hline 2020 & 0,33 & & $16,13 \%$ & 146 & 20 & 160 & 6 \\
\hline
\end{tabular}

Note: * - data on HS Code 85171200. 